\title{
Mesozooplankton omnivory in the upper San Francisco Estuary
}

\author{
Scott M. Gifford ${ }^{1, *}$, Gretchen Rollwagen-Bollens ${ }^{2}$, Stephen M. Bollens ${ }^{2}$ \\ ${ }^{1}$ Department of Marine Sciences, University of Georgia, Athens, Georgia 30602-3636, USA \\ ${ }^{2}$ School of Biological Sciences, Washington State University Vancouver, 14204 NE Salmon Creek Avenue, Vancouver, \\ Washington 98686-9600, USA
}

\begin{abstract}
While many studies have examined mesozooplankton feeding in coastal environments, less attention has been given to this subject in estuaries. We used bottle incubation experiments to measure the feeding rates of a cladoceran (Daphnia sp.), a calanoid copepod (Acartia spp.), and 2 cyclopoid copepods (Oithona davisae and Limnoithona tetraspina) on the protist plankton $(<200 \mu \mathrm{m})$ of Suisun Bay, which is located in the upper San Francisco Estuary (SFE). Nanoplankton (2 to $15 \mu \mathrm{m})$ prey were highly abundant (2000 to 6000 cells ml $^{-1}$ and 50 to $600 \mu \mathrm{g} \mathrm{C} \mathrm{l}^{-1}$ ), whereas microplankton

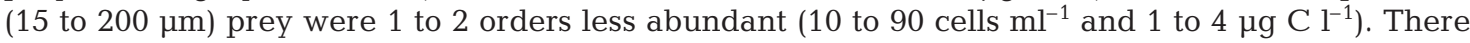
were few indications that mesozooplankton fed on nanoplankton, while microplankton were often significantly consumed. Daphnia sp. cleared all microplankton prey categories except diatoms at $>2 \mathrm{ml}$ predator (pred.) $)^{-1} \mathrm{~h}^{-1}$. O. davisae consumed only ciliates in September 2004, while in November 2004 it cleared both ciliates and diatoms at similar rates $\left(0.8 \mathrm{ml}\right.$ pred. $\left.{ }^{-1} \mathrm{~h}^{-1}\right)$. L. tetraspina cleared only aloricate ciliates and flagellates $\left(0.8\right.$ to $1.0 \mathrm{ml}$ pred..$\left.^{-1} \mathrm{~h}^{-1}\right)$. Acartia spp. had the highest clearance rates on diatoms of all the predators examined (mean $<1.0 \mathrm{ml}$ pred..$^{-1} \mathrm{~h}^{-1}$ ) but cleared ciliates at even higher rates $\left(>2.0 \mathrm{ml}\right.$ pred..$^{-1} \mathrm{~h}^{-1}$ ). With respect to biomass ingestion, in every experiment mesozooplankton were found to ingest ciliate carbon at the highest rates ( 3 to $29 \mathrm{ng} \mathrm{C} \mathrm{pred.}{ }^{-1} \mathrm{~h}^{-1}$ ). Our results indicate that while estuarine mesozooplankton are often omnivorous, important species-specific differences exist, and microzooplankton, especially ciliates, are an important component of the upper SFE food web.
\end{abstract}

KEY WORDS: Estuary $\cdot$ Mesozooplankton $\cdot$ Microzooplankton $\cdot$ Food web $\cdot$ Ciliates $\cdot$ Diatoms Resale or republication not permitted without written consent of the publisher

\section{INTRODUCTION}

In the last 2 decades, it has generally become accepted that microzooplankton (heterotrophic/mixotrophic protists 2 to $200 \mu \mathrm{m}$ ) are important components of marine systems (Pierce \& Turner 1992, RollwagenBollens \& Penry 2003, Calbet \& Landry 2004). We now know that microzooplankton are abundant, have high growth rates and are the major primary consumers in most marine systems (Pierce \& Turner 1992, Leaky et al. 1994, Calbet \& Landry 2004). Thus, pelagic food web models should consider both microzooplankton and phytoplankton.

Mesozooplankton are often the trophic intermediaries between microbial components (e.g. diatoms, fla- gellates, ciliates) and higher organisms, and feed on a wide variety of prey, including autotrophs, heterotrophs and mixotrophs (Stoecker \& Capuzzo 1990, Turner 2004). The degree to which mesozooplankton consume heterotrophic or autotrophic prey is, therefore, key to understanding the contribution of each to the upper food web.

The majority of research examining mesozooplankton feeding has focused on coastal seas, with relatively few studies conducted in estuaries (Turner 2004). Estuaries are dynamic environments where tidal mixing and freshwater input create large variations in salinity, temperature, turbidity and nutrient concentrations, all of which may affect protist plankton community composition (Iriarte et al. 2003, David et al. 2005) and 


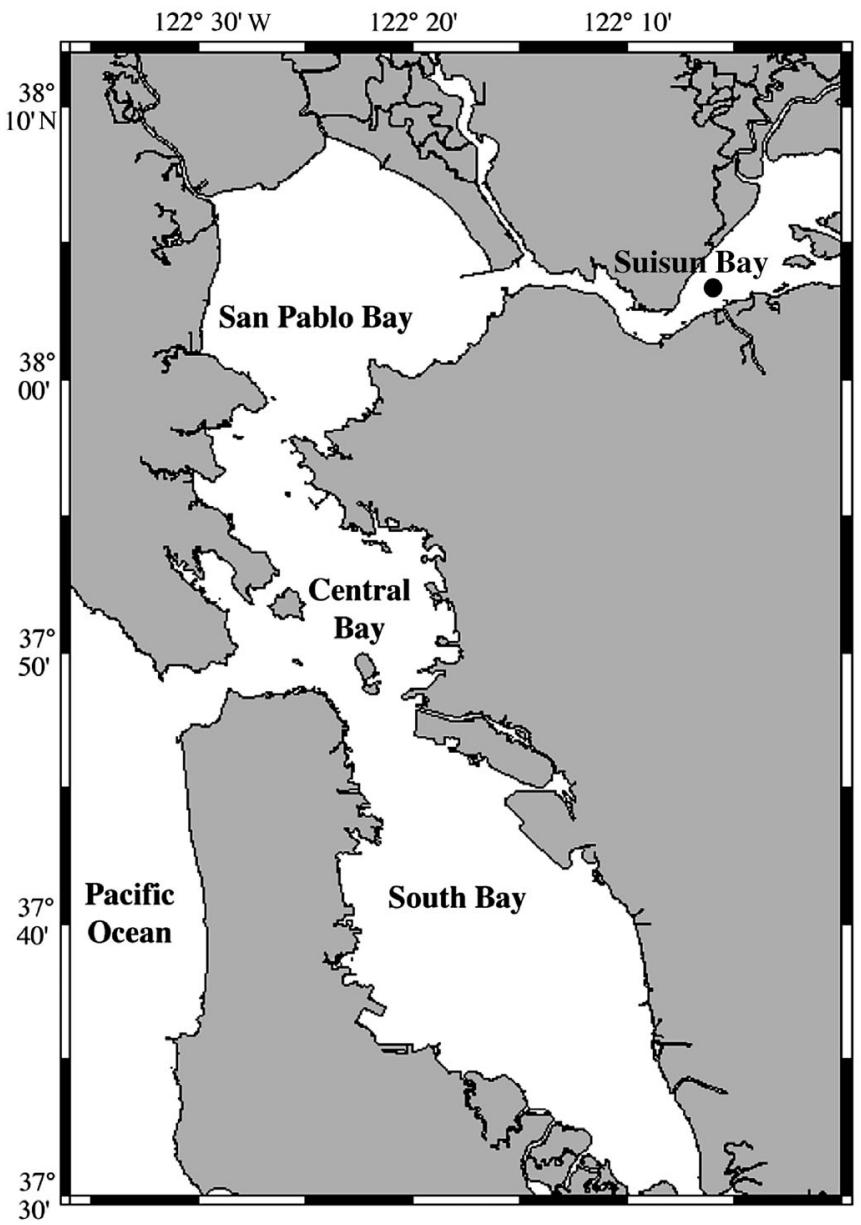

Fig. 1. San Francisco Estuary, California, USA. Sampling Stn $7($ ) is located within Suisun Bay

mesozooplankton feeding (Rollwagen-Bollens \& Penry 2003, Islam et al. 2005).

Microzooplankton are often highly abundant in estuaries (Buskey 1993, Rollwagen-Bollens \& Penry 2006), providing a potentially important food source to estuarine mesozooplankton. The high growth rates of microzooplankton allow them to closely track phytoplankton production in estuaries (Ambler et al. 1985, Cowlishaw 2004), and they are important grazers of estuarine primary production (Ruiz et al. 1998, Lionard et al. 2005).

Estuarine mesozooplankton have been observed to feed on both phytoplankton and microzooplankton (Gifford \& Dagg 1988, Ohman \& Runge 1994, Nakamura \& Turner 1997, Rollwagen-Bollens \& Penry 2003). Many of these studies have found seasonal variations in feeding, particularly during phytoplankton blooms (Fessenden \& Cowles 1994, Rollwagen-Bollens \& Penry 2003); mesozooplankton often ingest phytoplankton at higher rates than they ingest microzooplankton during such blooms. During non-bloom peri- ods, phytoplankton production may not be able to fully support mesozooplankton and microzooplankton become more important in the diet (Irigoien \& Castel 1995). However, microzooplankton are often cleared at higher rates than phytoplankton during both bloom and non-bloom periods (Gifford \& Dagg 1988, Rollwagen-Bollens \& Penry 2003). The calanoid copepod Acartia tonsa in a productive Gulf Coast estuary, for example, cleared ciliates at higher rates (1 to $4 \mathrm{ml}$ predator [pred. $]^{-1} \mathrm{~h}^{-1}$ ) than chlorophyll a (chl $a_{i}<1 \mathrm{ml}$ pred. $^{-1} \mathrm{~h}^{-1}$ ), even though phytoplankton represented the majority of carbon ingested (Gifford \& Dagg 1988). While a majority of these studies have focused on copepods, other fresh and brackish water taxa (including cladocerans and rotifers) can also be abundant in the upper estuary and can feed on both phytoplankton and microzooplankton.

Although several papers have recently described the composition of the mesozooplankton of the San Francisco Estuary (SFE) (Kimmerer \& Orsi 1996, Bollens et al. 2002, Hooff \& Bollens 2004), few studies have examined their feeding on microzooplankton. The goal of this study was to understand the relative importance of phytoplankton and microzooplankton in the diet of mesozooplankton in the upper SFE over a multiyear period. More specifically, we measured clearance and ingestion rates of 4 different mesozooplankton taxa (Daphnia sp., Limnoithona tetraspina, Oithona davisae and Acartia spp.) on the natural prey assemblage of protist plankton $(<200 \mu \mathrm{m})$ to discern seasonal and taxon specific differences in mesozooplankton feeding rates.

\section{MATERIALS AND METHODS}

Study site. Suisun Bay is located in the upper reaches of the SFE (Fig. 1), where freshwater input from the Sacramento and San Joaquin rivers meets saline coastal waters entering through the Golden Gate (Conomos et al. 1985). Winter rainfall and spring snowmelt increase freshwater flow into Suisun Bay, which creates a low salinity zone $(<2)$ from December to June. During the summer months freshwater input becomes highly reduced and the low salinity zone moves upstream of Suisun Bay.

The considerable size of the Sacramento and San Joaquin watershed (draining $40 \%$ of the surface area of California) results in the delivery of large amounts of sediment and organic material into Suisun Bay (Conomos et al. 1985). Bottom interactions sustain high amounts of suspended solids, and the bay is the site of an estuarine turbidity maximum. These conditions result in high nutrient levels and a shallow photic depth. Primary production is therefore light limited 
rather than nutrient limited (Alpine \& Cloern 1988, Cloern \& Dufford 2005). Primary production is low (39 $\mathrm{g} \mathrm{C} \mathrm{m}^{-2} \mathrm{yr}^{-1}$ ) due to both the light limited environment and grazing by the clam, Corbula amurensis (= Potamocorbula amurensis) (Alpine \& Cloern 1992). The bay typically experienced a phytoplankton bloom in the late spring $\left(30 \mu \mathrm{g} \mathrm{chl} \mathrm{a} \mathrm{l}^{-1}\right)$, but since the late 1980s the bloom has ceased to appear, most probably due to the invasion of $C$. amurensis in 1986 (Alpine \& Cloern 1992). Chl a now ranges from 1 to $10 \mu \mathrm{g} \mathrm{l}^{-1}$ with levels peaking in the spring (see sfbay.wr.usgs.gov/ access/wqdata).

Mesozooplankton feeding experiments. We conducted 9 feeding experiments that examined the mesozooplankton impact on nanoplankton ( 2 to $15 \mu \mathrm{m}$ ) and microplankton (15 to $200 \mu \mathrm{m}$ ) between March 2004 and August 2005. Experiments were conducted monthly during the spring (March to May) when chl a is typically elevated, and once in the late summer (August or September) in both 2004 and 2005. One additional experiment was conducted in November 2004. We collected samples at the US Geological Survey's (USGS) Water Quality Monitoring Program Stn $7\left(38^{\circ} 2.9^{\prime} \mathrm{N}, 122^{\circ} 5.8^{\prime} \mathrm{W}\right)$ to use the extensive archive of historical and current hydrographic data available for that site (see sfbay.wr.usgs.gov/access/ wqdata).

Temperature and salinity profiles were collected on site by means of a Seabird SBE 19 CTD. Water samples (2.5 l) were collected in Niskin bottles mounted on the CTD carousel for chl a analysis and to collect prey assemblages. We assessed water column profiles onboard to discern the depth at which to obtain water with intermediate temperature, salinity and fluorescence. We then lowered the CTD rosette to the chosen depth and tripped the Niskin bottles to collect the natural prey assemblage used in the incubations. The water was then siphoned via silicon tubing from the Niskin bottles directly into $500 \mathrm{ml}$ polycarbonate incubation bottles to ensure the least amount of damage to prey cells. All incubation bottles were sealed and transported to the lab (approx. $2 \mathrm{~h}$ ) in a dark container filled with bay water to maintain ambient temperature.

Mesozooplankton predators were collected with a ring net of $0.5 \mathrm{~m}$ diameter and $153 \mu \mathrm{m}$ mesh by means of multiple vertical tows and placed into a 201 bucket filled with surface bay water.

Chl a samples were filtered onto $47 \mathrm{~mm} \mathrm{GF/F} \mathrm{filters}$ and stored at $4{ }^{\circ} \mathrm{C}$ until extraction and analysis. Chlorophyll retained on the filters was extracted at room temperature in $90 \%$ acetone in the dark for $24 \mathrm{~h}$. Readings on a Turner 10AU fluorometer were taken before and after acidification with 3 drops of $10 \% \mathrm{HCl}$.

Feeding experiments were conducted using the protocol described by Gifford \& Dagg (1988) and Roll-
wagen-Bollens \& Penry (2003). The initial and final control bottles contained only the natural prey assemblage, while the treatment bottles contained both the prey assemblage and mesozooplankton predators. Four replicate incubation bottles were used in all experiments (i.e. 4 initial controls, 4 final controls and 4 treatments).

Both the mesozooplankton and prey assemblages were maintained at ambient temperatures while sorting for predators. After initially examining the mesozooplankton assemblage, we selected 1 or 2 numerically dominant taxa to be used as the predators for the feeding experiments. These were always copepods, except in March 2004 when the cladoceran Daphnia sp. was dominant (Table 1; see Rollwagen-Bollens \& Penry 2003 for description of Acartia spp.). Adult females of each mesozooplankton taxon were identified and sorted into 50 to $100 \mathrm{ml}$ holding vessels filled with 20 to $30 \mathrm{ml}$ of filtered ( $35 \mu \mathrm{m}$ ) bay water. Predators were then transferred to the treatment incubation bottles. Predator density in the incubation bottles ranged from 10 to 50 ind. per $500 \mathrm{ml}$ (Table 1). All incubation bottles were topped off with water containing the natural prey assemblage, sealed with Parafilm and a lid (to eliminate air spaces and turbulence causing bubbles), and placed on a plankton wheel rotating at $1 \mathrm{rpm}$. Incubations were $12 \mathrm{~h}$ long, and began between 17:30 and $22: 30 \mathrm{~h}$. Temperature $\left( \pm 1^{\circ} \mathrm{C}\right)$ and light conditions were set to mimic the ambient conditions at the sampling site. Initial control subsamples were preserved at the beginning of the incubation period (as described below) and final control and treatment subsamples were preserved at the end of the $12 \mathrm{~h}$ incubation period.

Table 1. Mesozooplankton used during feeding experiments. No. of ind. (n) is per $500 \mathrm{ml}$ incubation bottle

\begin{tabular}{|lll|}
\hline & Taxon & $\mathrm{n}$ \\
\hline $\mathbf{2 0 0 4}$ & & \\
March & Daphnia sp. & 10 \\
April & Limnoithona tetraspina & 40 \\
& Acartia spp. & 20 \\
May & Limnoithona tetraspina & 40 \\
September & Oithona davisae & 40 \\
November & Oithona davisae & 40 \\
& Acartia spp. & 20 \\
$\mathbf{2 0 0 5}$ & & 40 \\
March & Limnoithona tetraspina & 50 \\
April & Limnoithona tetraspina & 20 \\
& Acartia spp. & 50 \\
May & Limnoithona tetraspina & 20 \\
August & Acartia spp. \\
\hline
\end{tabular}


Microplankton subsamples $(200 \mathrm{ml})$ were preserved in $5 \%$ acid Lugols solution and stored in the dark at room temperature until analyzed (usually within $6 \mathrm{mo}$ of collection). Aliquots of $10 \mathrm{ml}$ were allowed to settle overnight in Utermöhl chambers for enumeration. Cells in the chamber were identified and enumerated using an inverted compound microscope (Olympus CK-40). Each cell >15 um was measured for length and width using an ocular micrometer. In the case of loricate ciliates, both the lorica and cell sizes were recorded. Due to the size distribution of the natural assemblage, we chose to use $15 \mu \mathrm{m}$ as the low end of the microplankton size range instead of the more commonly used $20 \mu \mathrm{m}$ (see RollwagenBollens \& Penry 2003 for justification). A minimum of 100 cells were enumerated per replicate. We assigned microplankton cells to 1 of 6 categories: diatoms, loricate ciliates, aloricate ciliates, Myrionecta rubra, flagellates and dinoflagellates. Though M. rubra (= Mesodinium rubrum) is an aloricate ciliate, it was readily identifiable in our samples and is known to ingest and maintain functional chloroplasts within its body (Johnson \& Stoecker 2005). While other aloricate ciliates present in our sample may also have been mixotrophic, the Lugols stain made confirmation of this impossible; thus, $M$. rubra was assigned a separate category from all the other aloricate ciliates.

Nanoplankton subsamples $(100 \mathrm{ml})$ were preserved in cold $1 \%$ glutaraldehyde, and stored at $4^{\circ} \mathrm{C}$ until processed. Within $7 \mathrm{~d}$ of collection, duplicate 10 to $20 \mathrm{ml}$ aliquots of each sample were stained for $10 \mathrm{~min}$ with $100 \mu \mathrm{l}$ of fluorescein isothiocyanate (FITC), filtered onto $25 \mathrm{~mm}$ diameter black polycarbonate filters (1.0 $\mu \mathrm{m}$ pore size), mounted on glass slides and kept in the dark at $0^{\circ} \mathrm{C}$ until analyzed (Sherr et al. 1993). Stained cells were identified, counted and sized at $400 \times$ magnification with an epiflourescence microscope (blue light excitation). We assigned nanoplankton cells to 4 prey categories: diatoms, dinoflagellates, non-pigmented flagellates and pigmented flagellates. Skeletonema costatum was included in the nanodiatom category. Although this diatom can form chains $>15 \mu \mathrm{m}$ in length, it was not feasible to count the high abundance of cells $\left(1500 \mathrm{ml}^{-1}\right)$ during bloom periods with the Utermöhl and inverted microscope method used for the microplankton. Fifty randomly selected fields of view were counted initially for each experiment to determine the between field variation. We then determined the number of fields of view required to achieve uniform variance (usually 30 to 35 fields). The remaining samples were enumerated by examining the determined number of fields. This typically resulted in a minimum of 100 cells enumerated per sample.
A group comparison $t$-test with equal variances was used to determine whether there was a significant difference between the number of cells in the final controls and treatments. Levene's test was used to test for equality of the variances. We applied the following criteria before accepting any experiment as valid: (1) a significant reduction $(\mathrm{p}<0.05)$ occurred in at least 1 prey category or taxa, and (2) the significantly reduced group had 5 or more cells in the final control.

Micro- and nanoplankton biovolumes were calculated by assigning geometric shapes to each taxon (as described in Wong \& Cloern 1982) and converted to carbon biomass values using equations from MendenDeuer \& Lessard (2000). Clearance rates (ml pred. ${ }^{-1}$ $\mathrm{h}^{-1}$ ) and carbon ingestion rates (ng C pred. ${ }^{-1} \mathrm{~h}^{-1}$ ) were calculated using equations from Marin et al. (1986). Pearson's correlation coefficients were used to compare feeding rates to prey abundances and hydrographic variables.

\section{RESULTS}

\section{Hydrography and chlorophyll}

Water column temperature increased steadily from $\sim 10^{\circ} \mathrm{C}$ in spring (March) to $\sim 22^{\circ} \mathrm{C}$ in fall (August or September), and dropped during late fall (November) in both 2004 and 2005 (Fig. 2). Water column salinity also steadily increased as the seasons progressed from the wet spring through the drier late summer and fall period (from 0.2 to 15.6 in 2004 and 4.3 to 7.3 in 2005). In general the profiles of temperature and salinity were relatively uniform with depth, except during April and May 2005 when the water column was more stratified with respect to salinity (Fig. 2)

Since the invasion of Corbula amurensis, high chl a levels have not been observed in the North SFE. However, a clear pattern in chl a abundance can still be seen (Cloern 1991; see http://sfbay.wr.usgs.gov/ access/wqdata). In winter, chl a levels are low, whereas in spring, peaks in chl a abundance can often be seen (Fig. 3). Later in the year, chl a levels drop, although occasionally levels increase in late fall. In our experiments, the natural prey assemblages were most often collected near mid-depth (Fig. 2), so we used the mid-depth chl $a$ as the best proxy for experimental chl a conditions. Mid-depth chl a levels

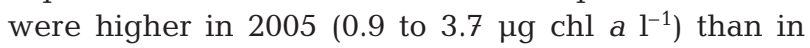

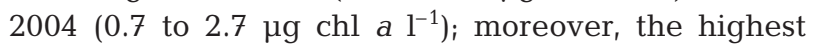
chl a values were seen in April of both years (Fig. 2). In addition, we also sampled near the end of a relatively high autumn peak in September 2004. 
Chlorophyll a $\left(\mu^{-1}\right)$
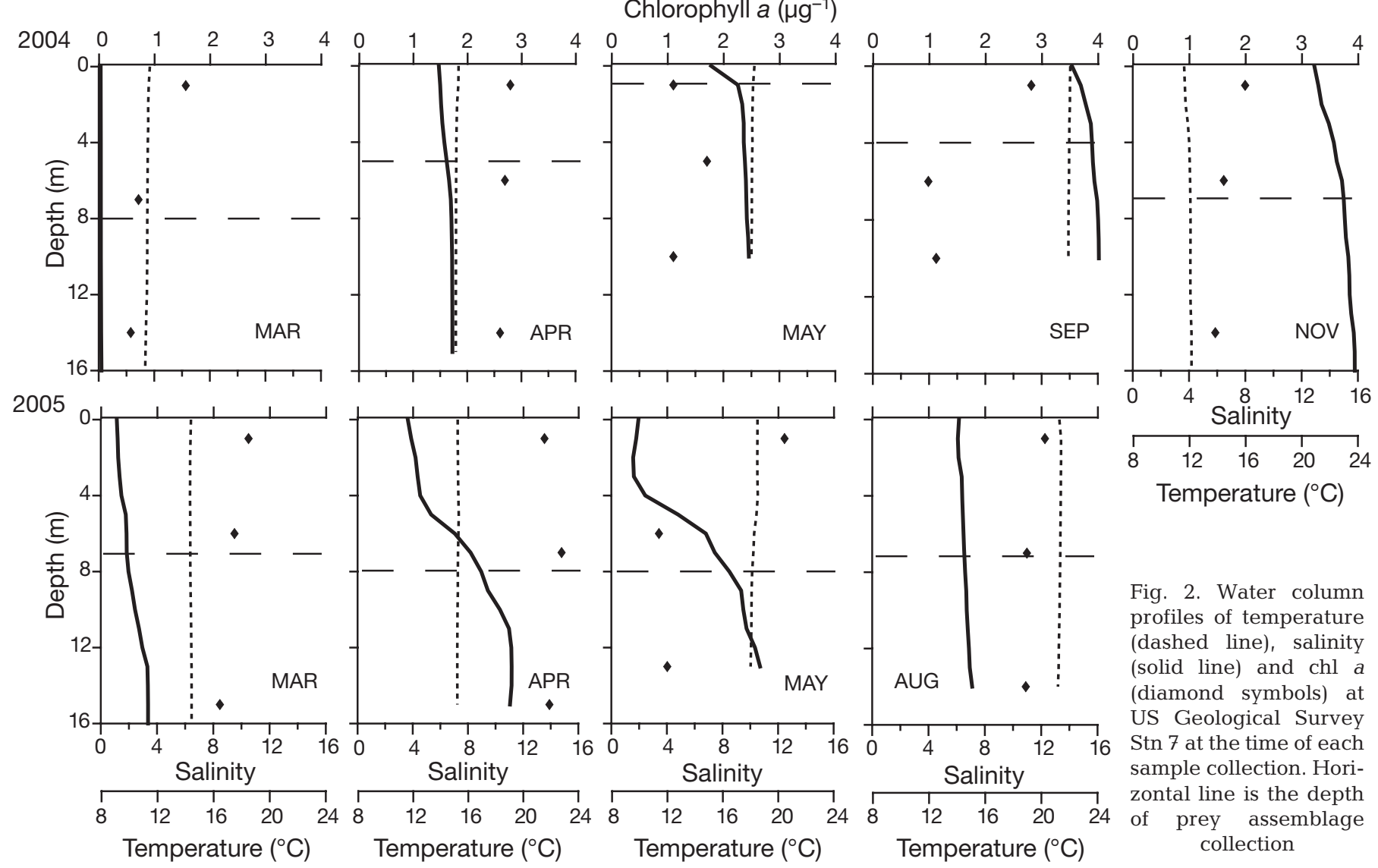

Fig. 2. Water column profiles of temperature (dashed line), salinity (solid line) and chl a (diamond symbols) at US Geological Survey Stn 7 at the time of each sample collection. Horizontal line is the depth of prey assemblage collection

\section{Available prey abundance and composition}

Nanoplankton (2 to $15 \mu \mathrm{m}$ ) were very abundant and contributed a substantial amount of carbon biomass (Fig. 4A,B). Small $(2 \mu \mathrm{m})$ nonpigmented nanoflagellates were highly abundant throughout the year, whereas pigmented flagellates contributed more to the available carbon biomass. Nanodiatoms were

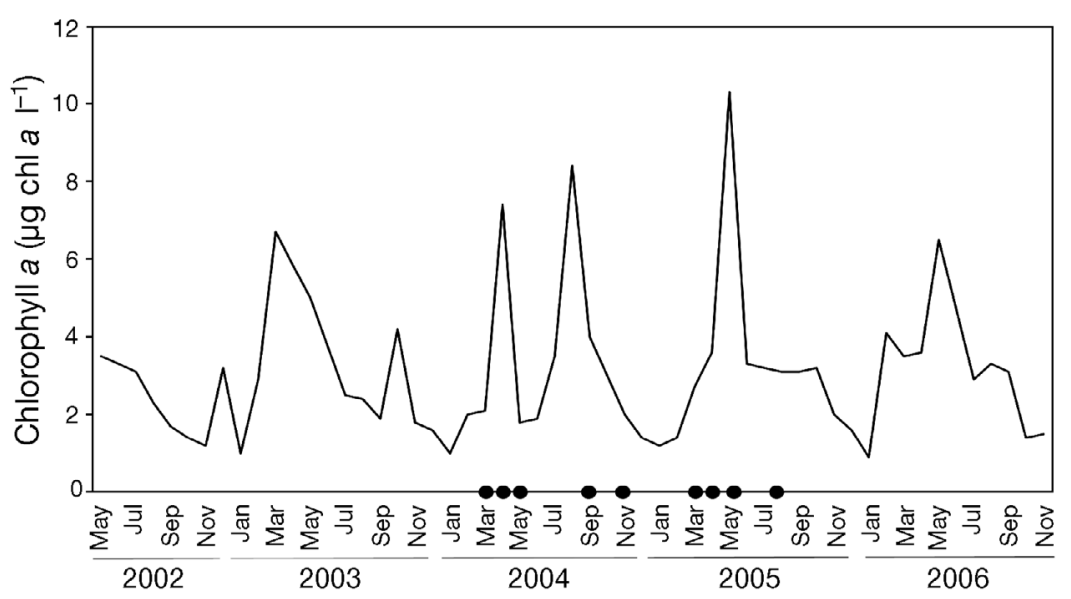

Fig. 3. Calculated chl a data from $2 \mathrm{~m}$ at Stn 7 collected by US Geological Survey from May 2002 through November 2006 (see http://sfbay.wr.usgs. gov/access/wqdata). (๑) dates of feeding experiments in the current study most abundant in April of both years. Skeletonema costatum represented 80 to $99 \%$ of nanodiatom abundance during these peak periods.

Microplankton (15 to $200 \mu \mathrm{m}$ ) abundances were 1 to 2 orders of magnitude lower than nanoplankton (Fig. 5A). Heterotrophic and mixotrophic protists (including Myrionecta rubra) made up an average of $73 \%$ of the total microplankton abundance; however, in March and April 2004 and March and May 2005, diatoms were proportionally the most abundant (Fig. 5A). In May 2004, M. rubra reached abundances of 14 cells $\mathrm{ml}^{-1}$. All microplankton categories, including ciliates, diatoms, and especially flagellates and dinoflagellates, increased in abundance in September 2004. In November 2004 and April 2005, diatoms and aloricate ciliates comprised $85 \%$ of the total abundance. In August 2005, aloricate ciliate abundances were relatively reduced, and loricate ciliates became relatively abundant (Fig. 5A).

Heterotrophic and mixotrophic protist biomass accounted for an average 
of $87 \%$ of the total microplankton carbon biomass (Fig. 5B). Aloricate ciliates often made the greatest contribution to this biomass, ranging from 45 to $75 \%$ of all nonautotrophic biomass. Diatoms made relatively small contributions ( 2 to $28 \%$ ) to the total carbon available. Flagellates and dinoflagellates made few significant contributions to microplankton biomass, with the notable exception of September 2004 when dinoflagellates (primarily Gymnodinium sp. and Alexandrium sp.) made up $43 \%$ of the total carbon available. Loricate ciliate biomass was often less than $10 \%$ of the total microplankton biomass, with the exception of August 2005 when loricate ciliates (primarily Tintinnopsis sp.) comprised $63 \%$ of the total microplankton biomass.

\section{Mesozooplankton feeding}

Despite nanoplankton dominance in terms of both abundance and biomass, there was little indication that mesozooplankton consumed nanoplankton prey. Nanoplankton prey categories were significantly $(\mathrm{p}<$ 0.05 ) reduced between the treatment and the final con- trol in only 1 feeding experiment (November 2004, nanodiatoms). Feeding was more clearly detected on the microplankton, which had a total of 17 instances of significant $(p<0.05)$ reduction in prey categories. All feeding rates discussed subsequently refer to microplankton unless otherwise stated.

No significant microplankton reductions occurred in the March and May 2005 experiments. These experiments, therefore, did not meet our criteria for a valid experiment and they were not considered further. In August 2005, no major category was significantly reduced. However, we did have 2 individual tintinnid taxa that were significantly reduced. One of those taxa had an average of $>5$ cells in the final control. Thus, by the criteria laid out in the methods, we included this experiment in our analyses.

Feeding rates were consistent throughout the $2 \mathrm{yr}$ sampling period. Despite substantial seasonal variability in total (2 to $200 \mu \mathrm{m}$ ) prey abundance and biomass, there was little variability in mesozooplankton feeding. In general, mesozooplankton feeding rates did not correlate with changes in prey abundance and biomass on either a seasonal or interannual basis (all $p$ values
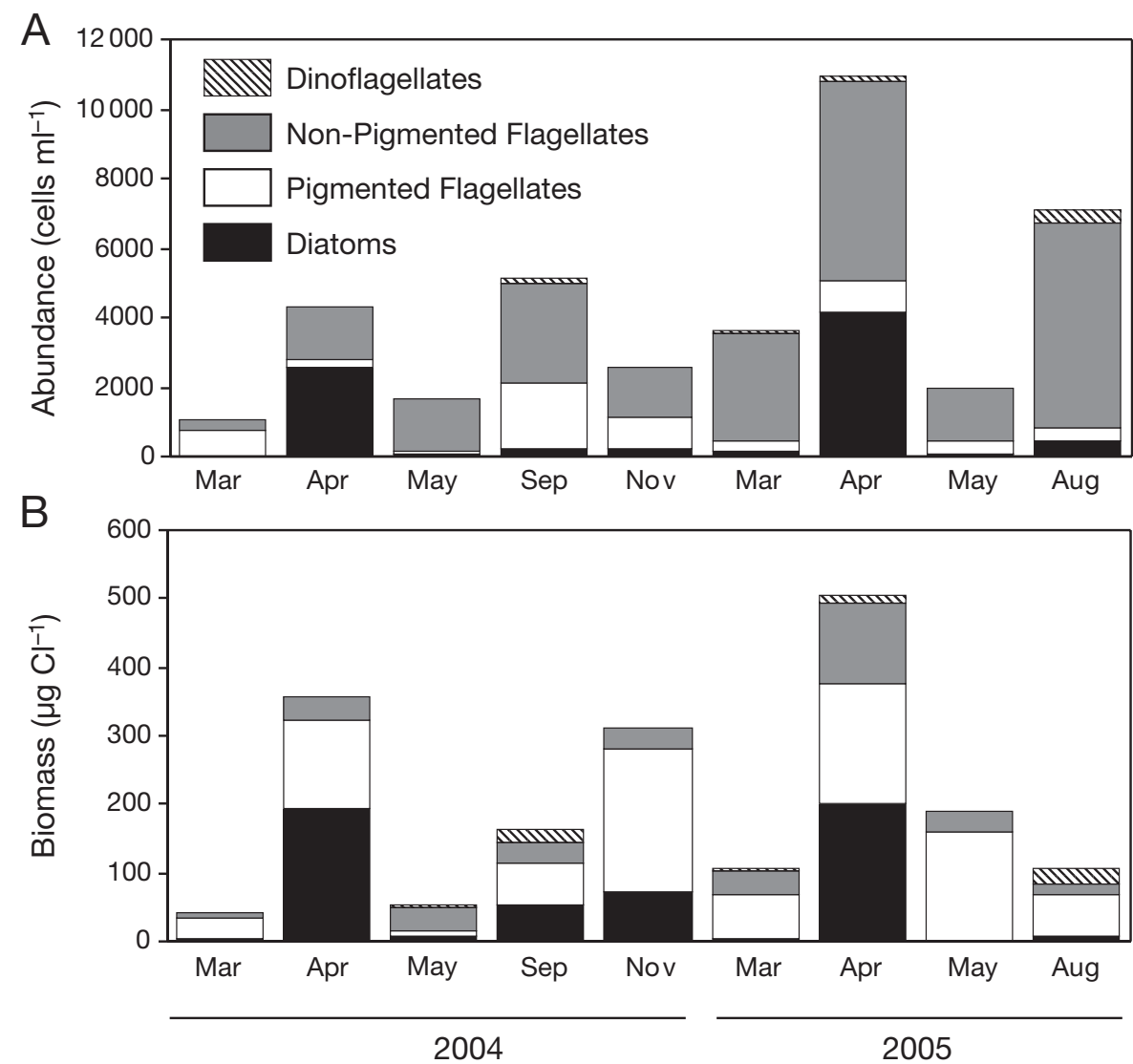

Fig. 4. Mean abundance (A) and carbon biomass (B) of nanoplankton (2 to $15 \mu \mathrm{m}$ ) prey categories available to predators during feeding experiments 


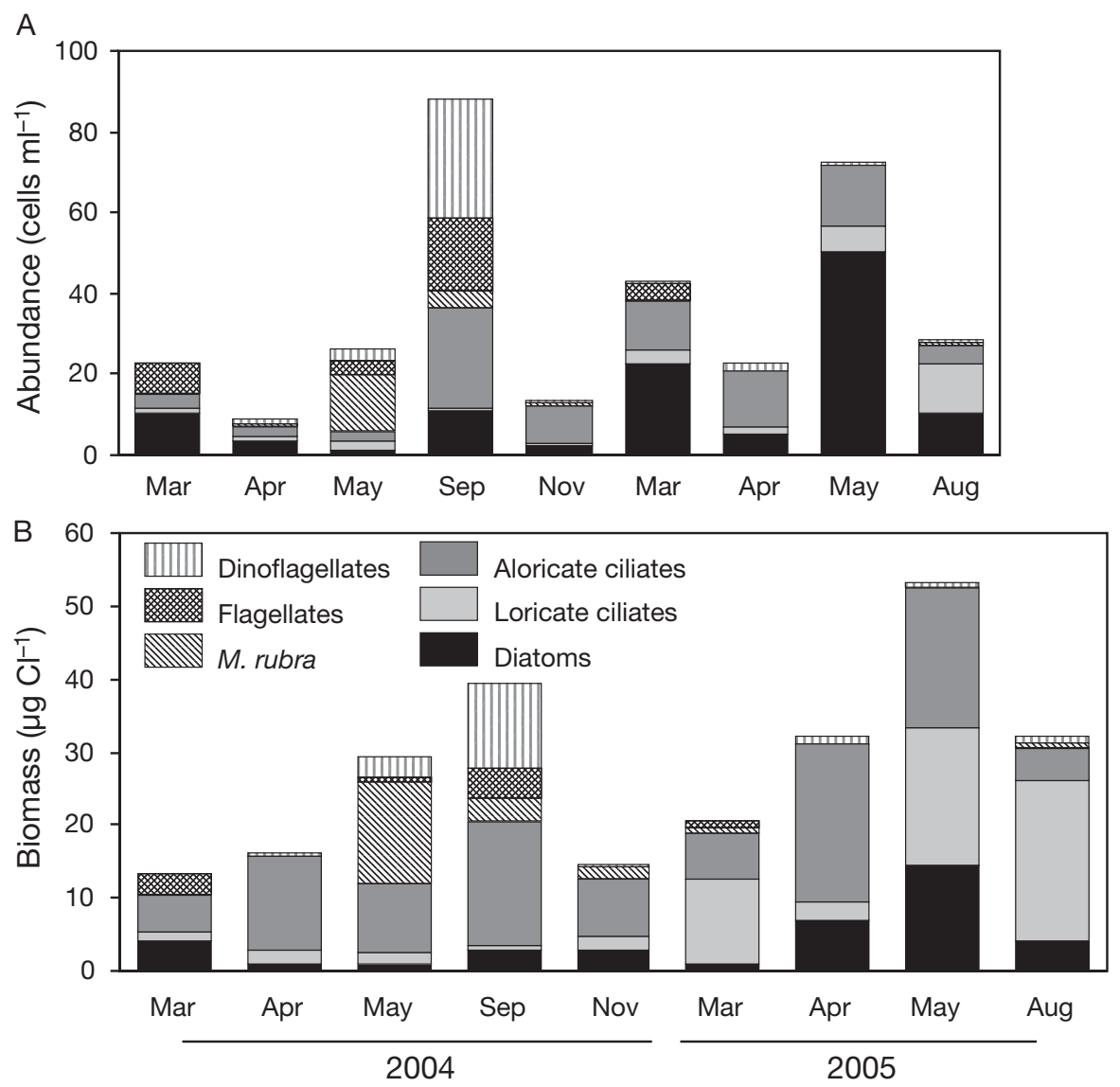

Fig. 5. Mean abundance (A) and carbon biomass (B) of microplankton (15 to $200 \mu \mathrm{m}$ ) prey categories available to predators during feeding experiments (M. rubra $=$ Myrionecta rubra)

$>0.25$ ). Feeding rates did not significantly increase in April when chl a peaked and nanodiatoms were highly abundant. However, when individual mesozooplankton predator taxa were examined separately, several trends emerged with respect to prey selectivity and overall ingestion rates.

\section{Individual predator feeding patterns}

\section{Clearance rates}

In March 2004, Daphnia sp. dominated the mesozooplankton assemblage and cleared loricate ciliates, aloricate ciliates and flagellates at comparable rates $\left(\sim 3 \mathrm{ml}\right.$ pred $\left.^{-1} \mathrm{~h}^{-1}\right)$ (Fig. 6A). In addition, significant reductions in several diatom taxa were observed during the incubation (e.g. Nitzchia sp. and Pseudonitzchia sp.), but overall clearance rates on diatoms was calculated as zero due to a substantial increase in the abundance of a single diatom species, Cerataulina pelagica, in the final controls (data not shown).
Limnoithona tetraspina were among the dominant mesozooplankton during 3 experimental periods in spring of 2004 and 2005. L. tetraspina cleared ciliates and flagellates at the highest rates in April and May 2004 (Fig. 6B). There was no significant difference between clearance rates on any prey categories in April 2005.

Oithona davisae were numerically dominant in summer and fall 2004. On an individual basis, O. davisae had clearance rates similar to Limnoithona tetraspina; aloricate ciliates, Myrionecta rubra, flagellates and dinoflagellates were cleared at $<1.0 \mathrm{ml}$ pred..$^{-1} \mathrm{~h}^{-1}$ in both September and November 2004 (Fig. 6C). The response to diatoms varied between these 2 months. In September, $O$. davisae cleared $0 \%$ of the total available diatom cells due to the significant increase of Cerataulina pelagica (the same diatom seen in March 2004 ) in the treatment bottles. In November, C. pelagica was not present and $O$. davisae cleared diatoms at a rate similar to ciliates and dinoflagellates. $O$. davisae also cleared loricate ciliates at rates 2 to 3 fold higher in September (completely clearing them from 3 of the 4 

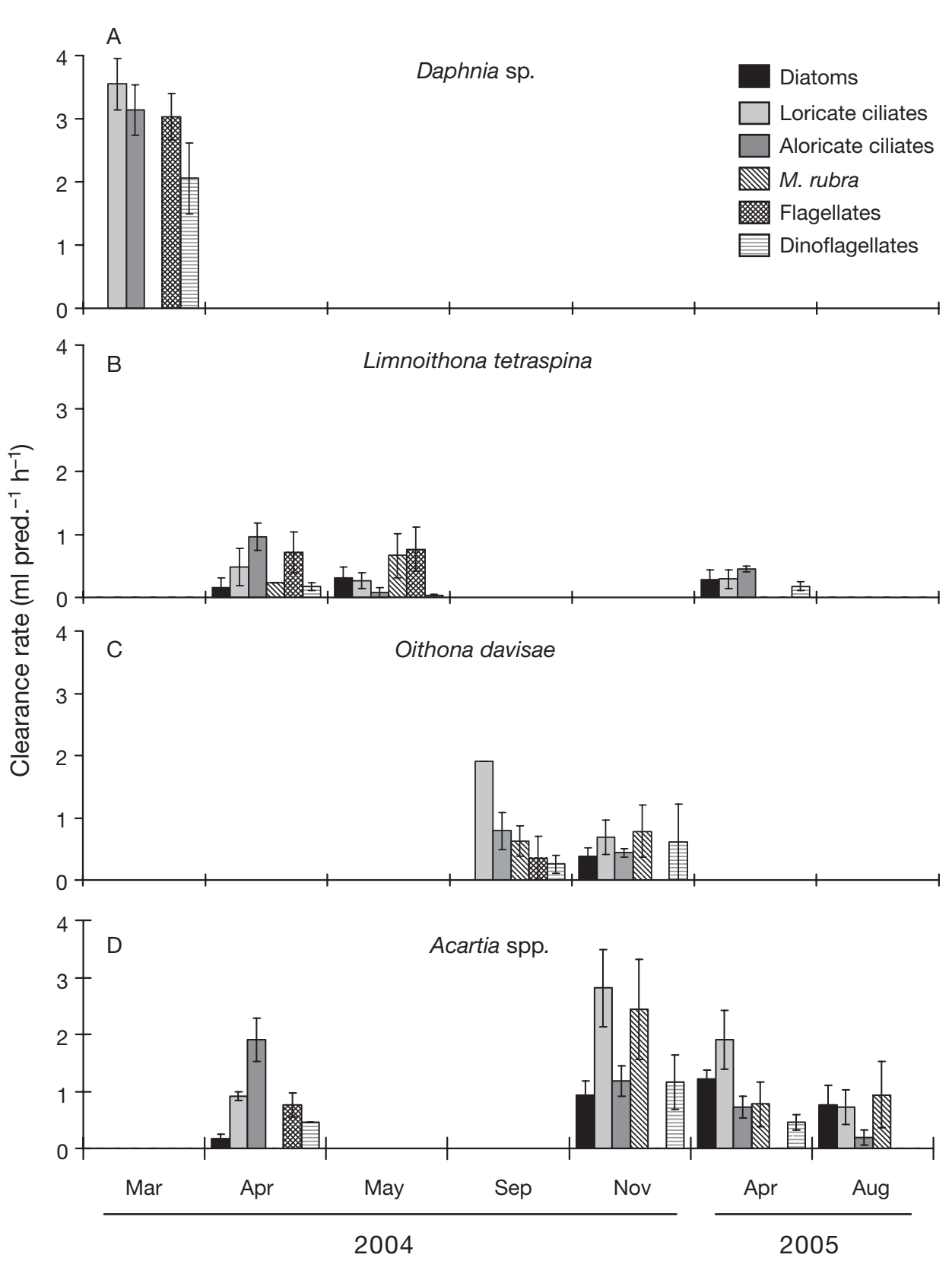

Fig. 6. Mean ( \pm SE) mesozooplankton clearance rates on microplankton (15 to $200 \mu \mathrm{m})$. (A) Daphnia sp., (B) Limnoithona tetraspina, (C) Oithona davisae, (D) Acartia spp. (M. rubra = Myrionecta rubra). SE could not be calculated for loricate ciliates in (C)

treatment bottles) compared with their clearance in November; O. davisae cleared loricate ciliates in November at rates similar to all other prey categories.

Acartia spp. were observed in 4 of the 9 sampling periods, particularly in April and November 2004 and April and August 2005. In each of these experiments Acartia spp. consistently cleared ciliates at rates higher than all other prey categories, although the category of ciliate preferred varied between experiments (Fig. 6D). Aloricate ciliates were cleared at the highest rates in April 2004, loricate ciliates and Myrionecta rubra were cleared at the highest rates in November
2004, and loricate ciliates were cleared at the highest rates in April 2005. In 3 out of the 4 experiments Acartia spp. also significantly cleared diatoms, although at more moderate rates $\left(\sim 1.0 \mathrm{ml}\right.$ pred..$\left.^{-1} \mathrm{~h}^{-1}\right)$ (Fig. 6D).

\section{Ingestion rates}

Daphnia sp. ingested aloricate ciliate carbon at 3 times the rate of all other prey categories (Fig. 7A). While Cerataulina pelagica comprised $42 \%$ of the diatom abundance, it only made up $11 \%$ of diatom car- 
bon biomass. Thus, Daphnia sp. overall diatom ingestion rate was $5.6 \mathrm{ng} \mathrm{C}$ pred. ${ }^{-1} \mathrm{~h}^{-1}$, which was similar to Daphnia sp. ingestion of loricate ciliates and flagellates. Limnoithona tetraspina ingested ciliate biomass at significantly higher rates than any other prey category (Fig 7B). In April of both years, aloricate ciliates were ingested at the highest rates. In May 2004, Myrionecta rubra biomass was highly abundant and $L$. tetrapsina ingested them at higher rates than aloricate ciliates. Oithona davisae also ingested aloricate ciliate biomass at the highest rates in both months it was present, although the rate in September 2004 was 3 times higher than in November 2004 (Fig. 7C). Acartia spp. ingested diatom carbon to a much lower degree than aloricate and loricate ciliates (Fig. 7D). Loricate ciliate biomass in particular was ingested at especially high rates (29 $\mathrm{ng} \mathrm{C}$ pred..$^{-1} \mathrm{~h}^{-1}$ ) in August 2005.

\section{DISCUSSION}

The goal of this study was to examine the food preferences and feeding rates of mesozooplankton in the upper SFE. Throughout the $2 \mathrm{yr}$ period the prey assemblage varied, but mesozooplankton consistently ingested heterotrophic protists, particularly ciliates. Our results are consistent with other studies that demonstrate microzooplankton are an integral component of the mesozooplankton diet.

\section{Seasonal variability}

Based on results of copepod feeding experiments in other parts of the SFE, as well as in other North American estuaries, we expected to observe a temporal signal in mesozooplankton feeding rates. For instance, in south San Francisco Bay, Rollwagen-Bollens \& Penry (2003) found that during periods of elevated chl a the majority of carbon ingested by Acartia spp. came from Skeletonema costatum, the same diatom we observed in high abundances in April 2004 and 2005. Gifford \& Dagg (1988) also found that Acartia spp. in a Gulf Coast estuary would ingest chl $a$ at higher rates than ciliates during periods of high phytoplankton standing stocks. Furthermore, Fessenden \& Cowles (1994) found that both clearance and ingestion rates on ciliates became reduced during times of increased phytoplankton biomass. In contrast, we did not observe a significant increase in ingestion rates on phytoplankton (or a decrease in ingestion rates on microzooplankton) during periods of elevated chl $a$.

However, the absence of a seasonal pattern in mesozooplankton feeding rates in our study is not surprising considering we saw few seasonal trends in microplankton $(>15 \mu \mathrm{m})$ prey availability despite a substantial bloom in nanoplankton (especially Skeletonema costatum) biomass in April of both years. Since mesozooplankton consumed only microplankton and never significantly reduced nanoplankton abundance in any experiment, and microplankton abundance showed little temporal variability throughout the experimental period, one would expect little seasonal or interannual variability in mesozooplankton feeding.

\section{Taxa-specific mesozooplankton clearance rates}

Our clearance rates suggest that different mesozooplankton predators exhibited preferences for different prey types. Daphnia sp. cleared all prey categories except diatoms at relatively high rates, suggesting primarily carnivorous feeding. However, Daphnia spp. are widely considered to be nonselective omnivores feeding on particles $<40 \mu \mathrm{m}$ in size (Mueller-Solger et al. 2002). They feed on a variety of prey types, including aloricate ciliates, flagellates, bacteria, detritus and diatoms. Upstream of Suisun Bay, in the Sacramento-San Joaquin delta, Daphnia sp. growth has been correlated to chl a (Mueller-Solger et al. 2002) and phytoplankton have been suggested as the primary component of its diet (Sobczak et al. 2002). Thus, it is likely that the lack of grazing by Daphnia sp. on diatoms in the March 2004 experiment was an anomaly. Indeed, diatoms were cleared by Daphnia sp. in this study, but the significant growth of Cerataulina pelagica in the treatment bottles obscured the feeding signal on other diatoms. When $C$. pelagica was removed from the diatom category, we calculated a clearance rate of $1.1 \mathrm{ml}$ pred. ${ }^{-1} \mathrm{~h}^{-1}$. In addition, we have observed Daphnia sp. from Suisun Bay to clear Skeletonema costatum at $1.7 \mathrm{ml}$ pred..$^{-1} \mathrm{~h}^{-1}$ in March 2004 (S. M. Gifford unpubl. data), further supporting the idea that it has an omnivorous diet. These diatom clearance rates, however, were only half the rates at which Daphnia sp. cleared microzooplankton, suggesting that although Daphnia sp. most probably do feed on diatoms, they may have a preference for heterotrophic protists in Suisun Bay.

Oithona davisae clearance rates indicate that it exhibited different prey preferences in September and November 2004. In September, O. davisae cleared ciliates at high rates while diatom abundances increased in the treatment bottles. While the increase in diatom abundances was similar to the Daphnia experiment in March 2004, the main difference was that when Cerataulina pelagica was removed from the diatom category, clearance and ingestion rates did not become significantly greater than zero, indicating that $O$. davisae 

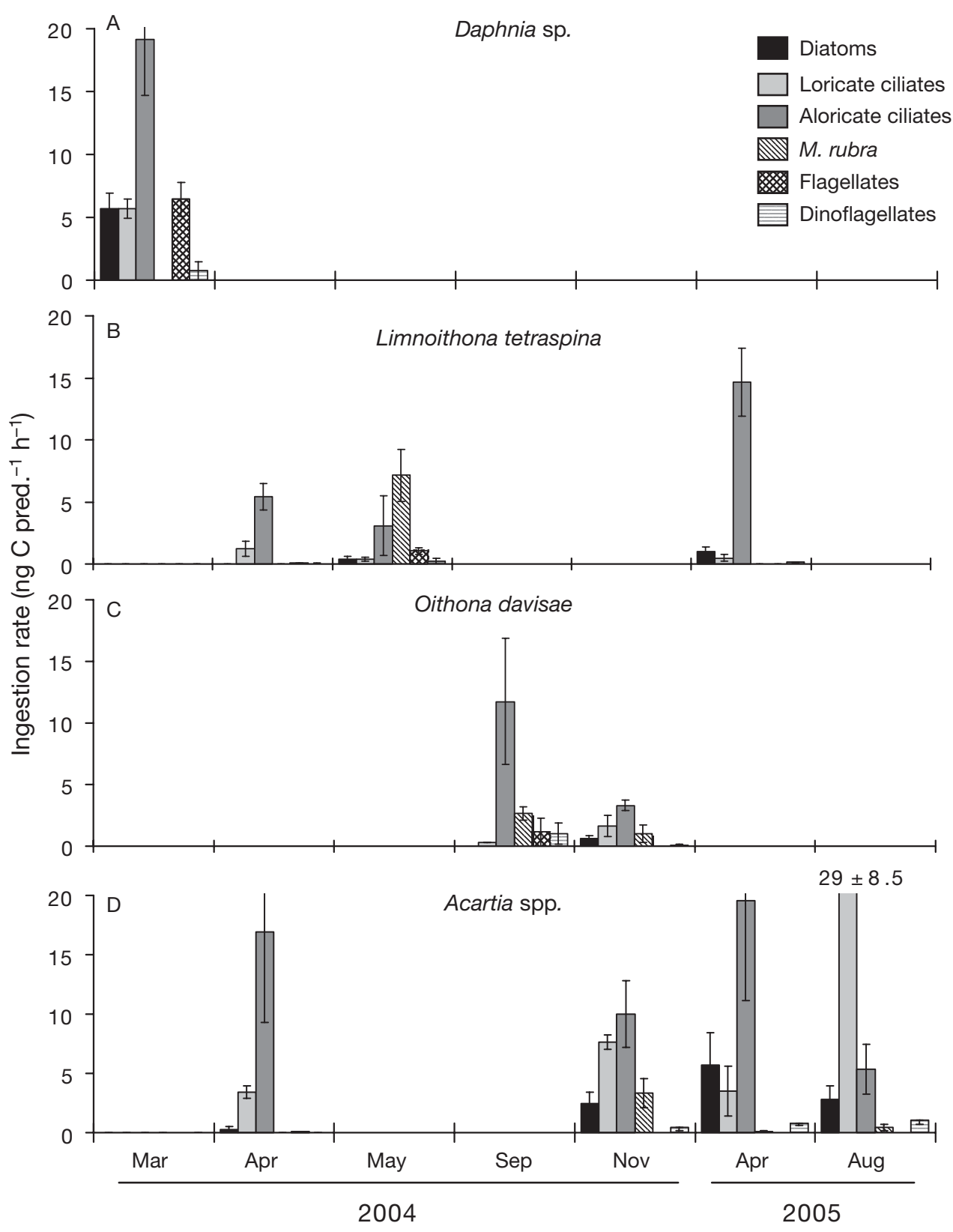

Fig. 7. Mean ( \pm SE) mesozooplankton ingestion rates on microplankton (15 to $200 \mu \mathrm{m})$. (A) Daphnia sp., (B) Limnoithona tetraspina, (C) Oithona davisae, (D) Acartia spp. (M. rubra = Myrionecta rubra)

avoided all diatoms during September. These results support the idea that members of the Oithonidae, including both $O$. davisae and Limnoithona tetraspina, are primarily carnivorous, feeding raptorially on motile prey (Turner 2004). Though this family is highly abundant throughout the world, relatively few studies have examined its feeding ecology, especially for $O$. davisae. Its congener, $O$. similis has received more attention. In Buzzards Bay, Massachusetts, O. similis preferred ciliates and dinoflagellates, with clearance rates similar to our observations for $O$. davisae $(<1.0 \mathrm{ml}$ pred..$^{-1} \mathrm{~h}^{-1}$ ) (Nakamura \& Turner 1997). Furthermore, ciliates have been found to contribute $91 \%$ of the carbon ration in $O$. similis diet in high latitude waters (Lonsdale et al. 2000).

Atkinson (1996), however, found that during one midsummer period, phytoplankton contributed $34 \%$ to the carbon diet of Oithona similis. Also, Islam et al. (2005) conducted gut pigment analysis of $O$. davisae in a Japanese estuary, and found that the diet was based mostly on chl $a$. These 2 findings support our November 2004 results in which $O$. davisae cleared all avail- 
able prey categories including diatoms at significantly similar rates. Our results suggest that in September, during maximum heterotrophic protist abundance, $O$. davisae preferentially fed on ciliates, and in November, when heterotrophic protist availability became reduced, $O$. davisae supplemented its diet with diatoms.

The feeding behavior of Limnoithona tetraspina suggests a mainly carnivorous diet, particularly because we observed no significant grazing impact on diatoms. Furthermore, clearance rates for April and May 2004 indicate that $L$. tetrapsina highly preferred aloricate ciliates and flagellates. Bouley \& Kimmerer (2006) also conducted feeding experiments with $L$. tetraspina in the upper SFE. Both their study and ours found $L$. tetraspina clearance rates to be low $\left(<1.0 \mathrm{ml}\right.$ pred. $^{-1}$ $\mathrm{h}^{-1}$ ) and that it fed almost exclusively on heterotrophic and mixotrophic ciliates with no significant reduction of diatoms or loricate ciliates.

Acartia spp. were the most omnivorous of all predators, clearing both diatoms and ciliates. Our results are consistent with other experiments showing that Acartia spp. will feed on loricate ciliates, aloricate ciliates, Myrionecta rubra, dinoflagellates and diatoms. While Acartia spp. will readily ingest both microzooplankton and phytoplankton, they prefer ciliates (Gifford \& Dagg 1988, Rollwagen-Bollens \& Penery 2003). All Acartia spp. experiments in our study resulted in at least one ciliate category cleared at a higher rate than diatoms or dinoflagellates.

Direct comparisons between these predators must be done with caution since they vary in body size and mass. Limnoithona tetraspina and Oithona davisae are relatively small compared with Acartia spp. and Daphnia sp. Though we did not weigh our predators, we do have weight data on related species of Acartia and Oithona from San Francisco Bay (Hutchinson 1982). These data allowed us to make at least one weight specific comparison of feeding rates between relatively large (Acartia) and small (Oithona) copepod taxa in November 2004. These results demonstrate that there is no change in relative prey preference of either predator when calculated on a weight specific basis (Fig. 8). However, the weight specific feeding rates for O. davisae are equal or higher than for Acartia spp. Thus, on a per unit weight basis, small abundant copepods such as $L$. tetraspina and $O$. davisae may have a greater feeding impact than the more thoroughly studied large copepod predators. More studies using weight specific feeding rates are needed to understand the ecological importance of these small copepods (Turner 2004).

A potential source of error for bottle incubation experiments is the increase of phytoplankton populations when grazing pressure by microzooplankton is reduced due to mesozooplankton grazing on microzooplankton (Nejstgaard et al. 2001). If this occurs, it will appear as if phytoplankton were not consumed by mesozooplanton and significant negative feeding rates may be observed. We probably observed such a phenomenon in March and September 2004. However, we believe the effect was limited to one particular taxa, Cerataulina pelagica, and in the case of the experiments conducted in September 2004 proved insubstantial. Dilution assays, in which microzooplankton grazing rates are quantified, are one way of examining what impact micrzoooplankton have on the phytoplankton community. We ran concurrent dilution assays with our bottle incubation experiments, the results of which will be discussed in another manuscript.

\section{Importance of microzooplankton biomass to mesozooplankton diet}

Though a great deal of variation was observed between predators in terms of clearance rates and prey selectivity, mesozooplankton always ingested ciliate biomass at the highest rates. The ciliate ingestion rates ( 3 to 29 ng C pred..$^{-1} \mathrm{~h}^{-1}$ ) we observed are comparable with other studies in estuaries (Ohman \& Runge 1994, Nakamura \& Turner 1997, reviewed in Calbet \& Saiz 2005) For example, Rollwagen-Bollens \& Penry (2003) observed Acartia spp. to ingest ciliates at 1.0 to $1.6 \mathrm{ng}$ C pred. ${ }^{-1} \mathrm{~h}^{-1}$ in north San Francisco Bay (San Pablo Bay) and at 0.02 to $20.0 \mathrm{ng} C$ pred. ${ }^{-1} \mathrm{~h}^{-1}$ in south San Francisco Bay. In Buzzards Bay, Massachusetts, Oithona similis ingested ciliates at a rate of 2.4 to $4.1 \mathrm{ng} \mathrm{C}$ pred. ${ }^{-1} \mathrm{~h}^{-1}$ (Nakamura \& Turner 1997). Similar ciliate ingestion rates by copepods have been observed in both laboratory and field experiments (Verity \& Paffenhofer 1996, Levinsen et al. 2000, Castellani et al. 2005). In addition, several studies have found that ciliates comprise $>50 \%$ of the carbon diet of mesozooplankton (Fessenden \& Cowles 1994, Lonsdale et al. 2000, Rollwagen-Bollens \& Penry 2003), and that ciliate carbon alone could meet daily respiration requirements (Fessenden \& Cowles 1994).

It is reasonable that ciliates could contribute such a large portion of carbon to the mesozooplankton diet in an area with low phytoplankton standing stocks, particularly since on average, ciliates are more carbon rich than diatoms of comparable volume (Menden-Deuer \& Lessard 2000), and have been reported to have as much as 4 times the carbon density of diatoms in the field (Ohman \& Runge 1994). Furthermore, when diatom biomass was high in our experiments, the diatom community was dominated by cells $<5 \mu \mathrm{m}$ in size (Skeletonema costatum). Ciliates are able to ingest 

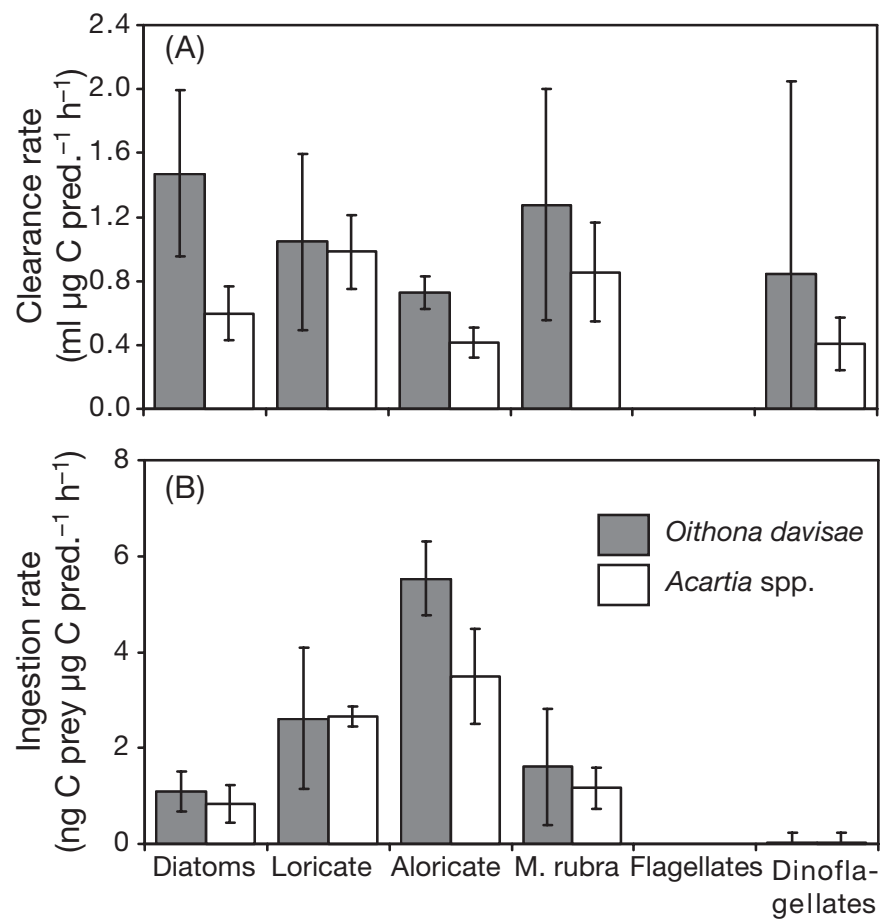

Fig. 8. Mean ( \pm SE) weight-specific (A) clearance and (B) ingestion rates on microplankton (15 to $200 \mu \mathrm{m}$ ) for Acartia spp. and Oithona davisae in November 2004 (M. rubra = Myrionecta rubra)

these small cells, potentially concentrating the large but dispersed phytoplankton biomass in particle sizes that can be consumed by mesozooplankton.

In addition to creating large carbon rich 'food packets,' microzooplankton may serve to trophically complement phytoplankton biomass. When mesozooplankton are fed low quality algae they are unable to grow well unless heterotrophic protists are a trophic intermediate (Klein Breteler et al. 1999). Tang \& Taal (2005), for example, found that Acartia sp. feeding on heterotrophic protists (Oxyrrhis marina) had higher egg production rates and hatching success than when feeding directly on the algae Dunaliella tertiolecta. The protists were found to produce an essential fatty acid missing in D. tertiolecta, suggesting they were complementing the algal biomass and making the diet more nutritious for Acartia. However, when high quality algae (Isochrysis galbana, Rhodomonas salina) were used instead of the low quality D. tertiolecta, egg production in Acartia was actually reduced when protists were used as an intermediate.

It has been hypothesized that during times of high phytoplankton abundances, mesozooplankton actively select for microzooplankton due to their higher nutrient composition. Tang \& Taal's (2005) findings, however, suggest that this shift to microzooplankton prey may not always be the most nutritious choice for mesozooplankton. The importance of microzooplankton in the diet depends on both phytoplankton quality and quantity. When phytoplankton are of high quality and abundance, the best feeding strategy may be to feed directly on phytoplankton. However, if phytoplankton are in high abundance, but of low quality, mesozooplankton may derive a majority of their carbon requirements from phytoplankton, but also need to supplement their diet with microzooplankton containing essential nutrients. The upper SFE represents a third scenario. Phytoplankton in this region may be of high quality (Cloern \& Dufford 2005), but are often in low abundance. Annual primary production in the SFE is $<40 \mathrm{~g} \mathrm{C} \mathrm{m}^{-2} \mathrm{yr}^{-1}$ (Alpine \& Cloern 1992) and chl a levels in the upper SFE are often $<10 \mu g \mathrm{l}^{-1}$ (see http://sfbay.wr.usgs.gov/access/wqdata). Furthermore, both Acartia spp. and Daphnia sp. in the upper SFE are food-limited due to low primary production as suggested by Mueller-Solger et al. (2002) and Kimmerer et al. (2005), and phytoplankton resources may be too low to sustain maximal growth and reproduction.

This low phytoplankton production and standing stock environment limits the contribution phytoplankton carbon can make to the mesozooplankton diet and may increase the importance of microzooplankton as a food source. This may be the reason we observed microzooplankton carbon to be ingested at such relatively high rates. In areas where primary production is low, microzooplankton are more likely to make greater contributions to the mesozooplankton diet (Calbet \& Saiz 2005).

On the other hand, in estuaries with high phytoplankton production mesozooplankton may ingest phytoplankton biomass at higher rates than ciliates (Gifford \& Dagg 1988). South San Francisco Bay, for example, experiences water column stratification (Cloern 1991), which isolates phytoplankton from the benthic grazer Corbula amurensis. Due to this isolation phytoplankton blooms are still seen in south San Francisco Bay, even though C. amurensis is present (Rollwagen-Bollens \& Penry 2003; see also sfbay. wr.usgs.gov/access/wqdata). Autotrophic plankton in this region contributed $50 \%$ of Acartia spp. diet (Rollwagen-Bollens \& Penry 2003). In north San Francisco Bay (adjacent to Suisun Bay, Fig. 1) the water column is well mixed and $C$. amurensis is believed to suppress any phytoplankton blooms. Heterotrophic ciliates in this region made up the majority of biomass ingested by Acartia spp. (Rollwagen-Bollens \& Penry 2003), results similar to this study. Ohman \& Runge (1994) compared Calanus finmarchicus ingestion rates and egg production in the St. Lawrence estuary and the Gulf of St. Lawrence (open water) and found that the importance of diatoms and ciliates to the copepod 
diet was inversely proportional to the concentration of chl a. In the chlorophyll rich waters of the estuary $C$. finmarchicus ingested diatoms at much higher rates than ciliates. However, in the waters of the Gulf containing relatively low chlorophyll, ciliates were ingested at 4 times the rate of diatoms. Interestingly, there was no significant difference in egg production by $C$. finmarchicus between the Gulf and the estuary, suggesting that $C$. finmarchicus was able to grow and reproduce well on either diatom or ciliate diets.

In summary, this study is the first to simultaneously examine multiple mesozooplankton predators in the SFE over a multiyear period. In doing so, we found microzooplankton may be especially important in the upper SFE, possibly due to relatively low amounts of phytoplankton. Ciliates in particular were consistently consumed at significant rates by all 4 predators. However, important species-specific differences exist. Our results support the growing body of evidence that microzooplankton are an important component of estuarine systems and that multiple links between phytoplankton, microzooplankton and mesozooplankton are needed to account for the many pathways that energy and materials may take to higher trophic levels.

Acknowledgements. Special thanks go to A. Slaughter, who provided invaluable help in the laboratory and thoughtful comments on the manuscript. Thank you to S. Cohen, S. Avent, D. Gewant, T. Ignoffo, P. Bouley and D. Marcal for their help and comments. We also thank D. Bell and D. Morgan of the RV 'Questuary' and everyone at the Romberg Tiburon Center. Funding for this study was provided by CALFED Bay-Delta Authority/California Sea Grant award no. R/SF-5 to G.R.-B. and S.M.B.

\section{LITERATURE CITED}

Alpine AE, Cloern JE (1988) Phytoplankton growth rates in a light-limited environment, San Francisco Bay. Mar Ecol Prog Ser 44:167-173

Alpine AE, Cloern JE (1992) Trophic interactions and direct physical effects control phytoplankton biomass and production in an estuary. Limnol Oceanogr 37:946-955

Ambler JW, Cloern JE, Hutchinson A (1985) Seasonal cycles of zooplankton from San Francisco Bay. Hydrobiologia 129:177-197

Atkinson A (1996) Subantarctic copepods in an oceanic, low chlorophyll environment: ciliate predation, food selectivity and impact on prey populations. Mar Ecol Prog Ser 130: 85-96

Bollens SM, Cordell JR, Avent S, Hooff R (2002) Zooplankton invasions: a brief review, plus two case studies from the northeast Pacific Ocean. Hydrobiologia 480:87-110

Bouley P, Kimmerer W (2006) Ecology of a highly abundant, introduced cyclopoid copepod in a temperate estuary. Mar Ecol Prog Ser 324:219-228

Buskey EJ (1993) Annual pattern of microzooplankton and mesozooplankton abundance and biomass in a subtropical estuary. J Plankton Res 15:907-924
Calbet A, Landry MR (2004) Phytoplankton growth, microzooplankton grazing, and carbon cycling in marine systems. Limnol Oceanogr 49:51-57

Calbet A, Saiz E (2005) The ciliate-copepod link in marine ecosystems. Aquat Microb Ecol 38:157-167

Castellani C, Irigoien X, Harris RP, Lampitt RS (2005) Feeding and egg production of Oithona similis in the North Atlantic. Mar Ecol Prog Ser 288:173-182

Cloern JE (1991) Tidal stirring and phytoplankton bloom dynamics in an estuary. J Mar Res 49:203-221

Cloern JE, Dufford R (2005) Phytoplankton community ecology: principles applied in San Francisco Bay. Mar Ecol Prog Ser 285:11-28

Conomos TJ, Smith RE, Gartner JW (1985) Environmental setting of San Francisco Bay. Hydrobiologia 129:1-12

Cowlishaw RJ (2004) Seasonal coupling between ciliate and phytoplankton standing stocks in the South Slough of Coos Bay, Oregon. Estuaries 27:539-550

David V, Sautour B, Chardy P, Leconte M (2005) Long-term changes of the zooplankton variability in a turbid environment: the Gironde estuary (France). Estuar Coast Shelf Sci 64:171-184

Fessenden L, Cowles TJ (1994) Copepod predation on phagotrophic ciliates in Oregon coastal waters. Mar Ecol Prog Ser 107:103-111

Gifford DJ, Dagg MJ (1988) Feeding of the estuarine copepod Acartia tonsa Dana: carnivory vs. herbivory in natural microplankton assemblages. Bull Mar Sci 43:458-468

Hooff RC, Bollens SM (2004) Functional response and potential predatory impact of Tortanus dextilobatus, a carnivorous copepod recently introduced to the San Francisco Estuary. Mar Ecol Prog Ser 277:167-179

Hutchinson A (1982) Plankton studies in San Francisco Bay. VI. Zooplankton species composition and abundance in the North Bay, 1979-1980. US Geol Surv Open File Rep 82-1003, September

Iriarte A, Madariaga I, Revilla M, Sarobe A (2003) Short-term variability in microbial food web dynamics in a shallow tidal estuary. Aquat Microb Ecol 31:145-161

Irigoien X, Castel J (1995) Feeding rates and productivity of the copepod Acartia bifilosa in a highly turbid estuary-the Gironde (SW France). Hydrobiologia 311:115-125

Islam MS, Ueda H, Tanaka M (2005) Spatial distribution and trophic ecology of dominant copepods associated with turbidity maximum along the salinity gradient in a highly embayed estuarine system in Ariake Sea, Japan. J Exp Mar Biol Ecol 316:101-115

Johnson MD, Stoecker DK (2005) Role of feeding in the growth and photophysiology of Myrionecta rubra. Aquat Microb Ecol 39:303-312

Kimmerer W, Orsi JJ (1996) Changes in the zooplankton of the San Francisco Bay estuary since the introduction of the clam Potamocrobula amurensis. In: Hollibaugh JT (ed) San Francisco Bay: the ecosystem. Pac Div Am Assoc Adv Sci, San Francisco, CA

Kimmerer W, Ferm N, Nicolini MH, Penalva C (2005) Chronic food limitation of egg production in populations of copepods of the genus Acartia in the San Francisco Estuary. Estuaries 28:541-550

Klein Breteler W, Schogt N, Baas M, Schouten S, Kraay GW (1999) Trophic upgrading of food quality by protozoans enhancing copepod growth: role of essential lipids. Mar Biol 135:191-198

Leakey RJG, Burkill PH, Sleigh MA (1994) Ciliate growth rates from Plymouth Sound: comparison of direct and indirect estimates. J Mar Biol Assoc UK 74:849-861

Levinsen H, Turner JT, Nielsen TG, Hansen BW (2000) On the 
trophic coupling between protists and copepods in arctic marine ecosystems. Mar Ecol Prog Ser 204:65-77

Lionard M, Azemar F, Bouletreau S, Muylaert K, Tackx M, Vyverman W (2005) Grazing by meso- and microzooplankton on phytoplankton in the upper reaches of the Schelde estuary (Belgium/The Netherlands). Estuar Coast Shelf Sci 64:764-774

Lonsdale DJ, Caron DA, Dennett MR, Schaffner R (2000) Predation by Oithona spp. on protozooplankton in the Ross Sea, Antarctica. Deep-Sea Res II 47:3273-3283

Marin V, Huntley ME, Frost B (1986) Measuring feeding rates of pelagic herbivores: analysis of experimental design and methods. Mar Biol 93:49-58

Menden-Deuer S, Lessard EJ (2000) Carbon to volume relationships for dinoflagellates, diatoms, and other protist plankton. Limnol Oceanogr 45:569-579

Mueller-Solger AB, Jassby AD, Mueller-Navarra DC (2002) Nutritional quality of food resources for zooplankton (Daphnia) in a tidal freshwater system (Sacramento-San Joaquin River Delta). Limnol Oceanogr 47:1468-1476

Nakamura Y, Turner JT (1997) Predation and respiration by the small cyclopoid copepod Oithona similis: How important is feeding on ciliates and heterotrophic flagellates? J Plankton Res 19:1275-1288

Nejstegaard JC, Naustvoll LJ, Sazhin A (2001) Correcting for underestimation of microzooplankton grazing in bottle incubation experiments with mesozooplankton. Mar Ecol Prog Ser 221:59-75

Ohman MD, Runge JA (1994) Sustained fecundity when phytoplankton resources are in short supply-omnivory by Calanus finmarchicus in the Gulf of St. Lawrence. Limnol Oceanogr 39:21-36

Pierce RW, Turner JT (1992) Ecology of planktonic ciliates in marine food webs. Rev Aquat Sci 6:139-181

Editorial responsibility: Barry Sherr (Contributing Editor), Corvallis, Oregon, USA
Rollwagen-Bollens GC, Penry DL (2003) Feeding dynamics of Acartia spp. copepods in a large, temperate estuary (San Francisco Bay, CA). Mar Ecol Prog Ser 257:139-158

Rollwagen-Bollens GC, Penry DL (2006) Vertical distribution of micro- and nanoplankton in the San Francisco Estuary in relation to hydrography and predators. Aquat Microb Ecol 44:143-163

Ruiz A, Franco J, Villate F (1998) Microzooplankton grazing in the estuary of Mundaka, Spain, and its impact on phytoplankton distribution along the salinity gradient. Aquat Microb Ecol 14:281-288

Sherr EB, Caron DA, Sherr BF (1993) Staining of heterotrophic protists for visualization via epifluorescence microscopy. In: Kemp PF, Sherr EB, Sherr BF, Cole JJ (eds) Handbook of methods in aquatic microbial ecology. Lewis Publishers, Boca Raton, FL

Sobczak WV, Cloern JE, Jassby AD, Mueller-Solger AB (2002) Bioavailability of organic matter in a highly disturbed estuary: the role of detrital and algal resources. Proc Natl Acad Sci USA 99:8101-8105

Stoecker DK, Capuzzo JM (1990) Predation on protozoa: its importance to zooplankton. J Plankton Res 12:891-908

Tang KW, Taal M (2005) Trophic modification of food quality by heterotrophic protists: species-specific effects on copepod egg production and egg hatching. J Exp Mar Biol Ecol 318:85-98

Turner JT (2004) The importance of small planktonic copepods and their roles in pelagic marine food webs. Zool Stud 43:255-266

Verity PG, Paffenhofer GA (1996) On assessment of prey ingestion by copepods. J Plankton Res 18:1767-1779

Wong PS, Cloern JE (1982) Plankton studies in San Francisco Bay. IV. Phytoplankton abundances and species composition. US Geol Surv Open File Rep 82-443, April

Submitted: April 15, 2006; Accepted: April 2, 2007

Proofs received from author(s): October 5, 2007 